\title{
Studi Degreening, Kesegaran, dan Daya Simpan Buah Naga Merah (Hylocereus polyrhizus (Weber) Britton \& Rose) untuk Menentukan Kriteria Panen Optimum
}

\author{
Studies on Degreening, Freshness, and Fruit Shlef-life of Red Dragon Fruit \\ (Hylocereus polyrhizus (Weber) Britton \& Rose) for Optimum Harvest Criteria
}

\author{
Winarso Drajad Widodo ${ }^{1}$, Ketty Suketi ${ }^{1 *}$, dan Farah Maulida ${ }^{2}$ \\ ${ }^{1}$ Departemen Agronomi dan Hortikultura, Fakultas Pertanian, Institut Pertanian Bogor \\ (IPB University), Jl. Meranti, Kampus IPB Darmaga, Bogor 16680, Indonesia \\ ${ }^{2}$ Program Studi Agronomi dan Hortikultura, Departemen Agronomi dan Hortikultura, Institut Pertanian Bogor
}

Diterima 27 Oktober 2020/Disetujui 1 Desember 2020

\begin{abstract}
Red dragon fruit is a non-climacteric fruit with a photosynthetic crassulacean acid metabolism pathway. The optimum maturity is characterized by a 100\% red skin color. The aim of the experiment was to study the changes in color, freshness, and shelf life of red dragon fruit to determine the optimum harvest criteria. The fruits were harvested from Sabisa Farm, Sindang Barang, Bogor (60 35 '16" S, 1,060 46" E; elevation $219 \mathrm{~m}$ above sea level). The experiment used a complete randomized block design with 5 levels of harvesting age, namely 30, 32, 34, 36, and 38 days after anthesis (DAA) with 5 replications. The results showed that the skin of 30 DAA fruit has a color scale of $2(1-25 \%$ red) and 32 DAA fruit has a color scale of $4(26-50 \%$ red). Fruit 34, 36, and 38 DAA had reached a color scale of $6(100 \%$ red $)$ when harvested. The skin of 30 DAA fruit takes 6 days after harvest (DAH) and 32 DAA fruit takes 3 DAH to reach a color scale of $6(100 \%$ red $)$. On the 6 color scale, the fruits of 30 to 38 DAA had a total soluble solids content of 11.7 to $13.5^{\circ}$ Brix which still meets the dragon fruit marketing standard of $11.0^{\circ} \mathrm{Brix}$. The total titrated acid content decreased, but the vitamin $C$ content increased with increasing harvest age.
\end{abstract}

Keywords: CAM, fruit freshness, heat unit, long-day plant, postharvest ripeness

\section{ABSTRAK}

Buah naga merah adalah buah non klimakterik dengan lintasan fotosintesis crassulacean acid metabolism. Kematangan optimum ditandai dengan warna kulit buah merah $100 \%$. Tujuan percobaan adalah mempelajari perubahan warna kulit terkait dengan kesegaran dan daya simpan buah naga merah untuk menentukan kriteria panen optimum. Bahan percobaan disiapkan di kebun Sabisa Farm, Sindang Barang, Bogor (60 35'16" LS, 1060 46' BT; elevasi 219 m di atas permukaan laut). Percobaan menggunakan rancangan kelompok lengkap teracak dengan perlakuan 5 taraf umur panen, yaitu 30, 32, 34, 36, dan 38 hari setelah antesis (HSA) dengan 5 ulangan. Hasil percobaan menunjukkan bahwa kulit buah naga merah 30 HSA memiliki skala warna 2 (1-25\% merah), buah 32 HSA memiliki skala warna 4 (26-50\% merah), dan buah 34, 36, dan 38 HSA telah mencapai skala warna 6 (100\% merah) ketika dipanen. Kulit buah 30 HSA memerlukan waktu 6 hari setelah panen (HSP) dan buah 32 HSA memerlukan waktu 3 HSP untuk mencapai warna merah 100\%. Pada saat warna merah 100\%, buah 30-38 HSA memiliki kandungan padatan terlarut total 11.7 hingga $13.5^{\circ}$ Brix yang masih memenuhi standard pemasaran buah naga sebesar $11.0^{\circ}$ Brix. Kandungan asam tertitrasi total menurun, tetapi kandungan vitamin C meningkat dengan meningkatnya umur panen.

Kata kunci: CAM, kematangan pascapanen, kesegaran buah, satuan panas, tanaman hari-panjang

\section{PENDAHULUAN}

Buah naga (Hylocereus polyrhizus (Weber) Britton \& Rose) termasuk buah non-klimakterik, dengan lintasan fotosintesis ceassulacean acid metabolism (CAM) (Mizrahi, 2015). Saat panen terbaik buah naga adalah pada tingkat

\footnotetext{
* Penulis untuk korespondensi. e-mail: wdwidodo@gmail.com
}

matang penuh (full ripe) di pohon (Rebecca et al., 2010; Choudhury et al., 2018) yang memiliki tingkat edibilitas terbaik (De Freitas dan Mitcham, 2013). Perubahan warna kulit buah naga setelah panen mengikuti pola perubahan warna kulit buah klimakterik, yaitu perubahan warna dari hijau ke merah (Hoa et al., 2006; Hua et al., 2018). Dengan demikian buah naga dapat dipanen sebelum matang penuh, kemudian diperam untuk proses degreening seperti pada 
buah jeruk (Paul et al., 2012). Perubahan warna kulit buah naga dapat ditingkatkan dengan penyimpanan pada suhu dingin $\left(4^{\circ} \mathrm{C}\right)$ tanpa penyinaran (Woo et al., 2011).

Buah naga merah (H. polyrhizus (Weber) Britton \& Rose) mengandung pigmen dominan betasianin yang berkhasiat antioksidan, sehingga membuat buah naga dapat digunakan sebagai pangan berkhasiat, bahan industri pewarna pangan, dan sumber senyawa antioksidan (Lourith dan Kanlayavattanakul, 2013; Priatni dan Pradita, 2015; Maigoda et al., 2017). Buah naga adalah satu-satunya buah dengan kandungan betasianin tinggi yang dapat dikonsumsi segar (Hua et al., 2016).

Buah naga termasuk tanaman crassulacean acid metabolism (CAM) (Mizrahi, 2015) yang tergolong tanaman hari panjang (LDP) dengan panjang penyinaran kritis 12 jam/hari (Khaimov dan Mizrahi, 2006; Jiang et al., 2012; Jiang et al., 2016; Patil et al., 2019). Keunikan buah naga sebagai tanaman CAM adalah keberadaan stomata pada permukaan kulit dan jumbai (sisik) buah. Kapadatan stomata jumbai lebih tinggi dibandingkan pada kulit buah, sehingga kesegaran jumbai adalah indikator penting kesegaran buah (Mizrahi, 2015).

Keberadaan stomata pada kulit dan jumbai buah diduga merupakan faktor pendukung kecepatan pembesaran buah naga. Hal ini menyebabkan kriteria panen berdasarkan umur buah menjadi bervariasi. Hasil karakterisasi Mizrahi (2015) di Israel mendapatkan tahap buah layak dipanen dicapai pada 28-29 hari setelah antesis (HSA), di Malaysia pada 30-35 HSA (Naderi et al., 2012), di Bangladesh pada 32-33 HSA (Patwary et al., 2013), di China pada 27 HSA (Hua et al., 2018), dan di Taiwan untuk buah naga di luar musim pada 46-59 hari (Tran et al., 2015). Di pulau Jawa, buah naga biasa dipanen pada 30-35 HSA. Istianingsih dan Efendi (2013) dalam penelitiannya tentang kesegaran buah naga super-red (H. costaricensis ) yang dipanen pada 33, 35, dan 37 HSA mendapatkan hasil bahwa saat panen terbaik adalah 35 HSA, yang dengan suhu penyimpanan 15 ${ }^{0} \mathrm{C}$ kesegaran buah dapat dipertahankan hingga 21 hari lebih lama jika dibandingkan dengan penyimpanan pada suhu ruangan.

Buah naga termasuk tanaman hari panjang dengan panjang penyinaran dapat diinduksi pembungaannya di luar musim dengan cara penambahan penyinaran, pemutusan malam (night-breaking), dan perlakuan zat pengatur tumbuh (Jiang et al. 2012; Tran et al., 2015; Jiang et al., 2016). Praktik ini telah dilakukan di Indonesia pada pertanaman buah naga petani baik dengan penambahan penyinaran maupun dengan night-breaking (Hidayah et al., 2016; Setyawati, 2019), sehingga buah naga dapat dibungakan sepanjang tahun. Kelemahan buah naga hasil induksi pembungaan di luar musim adalah penampilan warna buah yang buruk dengan kemanisan rendah, yang diduga karena panjang penyinaran yang lebih pendek dibanding panjang penyinaran pada pembungaan buah naga alami.

Buah naga di pulau Jawa, secara alami berbunga pada musim hujan (Oktober-Maret) dengan mutu penampilan yang baik yaitu warna merah kulit buah dan warna hijau jumbai buah yang lebih kuat dibandingkan dengan buah hasil induksi di luar musim. Sebagai buah untuk konsumsi segar, buah naga hasil induksi pembungaan di luar musim dengan kualitas yang kurang baik, akan kalah bersaing dengan buah impor dari hemisfir Utara yang kualitasnya lebih baik karena berbunga sesuai musimnya dengan penyinaran yang lebih panjang. Rendahnya kualitas buah di luar musim diduga karena penggunaan kriteria panen yang sama, yaitu warna kulit buah yang merah $100 \%$.

Sebagai buah dengan kandungan betasianin tinggi yang dapat dikonsumsi segar, buah naga merah telah diteliti sebagai sumber senyawa antioksidan dan bahan pewarna alami yang baik. Sementara itu, selain umur panen yang bervariasi, informasi tentang hubungan warna kulit dan daging buah naga merah saat panen belum tersedia. Oleh karena itu, sebagai tahap awal perlu dipelajari degreening pascapenen pada buah naga merah dengan pembungaan alami sesuai musim terkait dengan daya simpan untuk penentuan kriteria panen terukur yang kemungkinan dapat diterapkan sebagai kriteria panen untuk buah naga off-season. Percobaan ini bertujuan mempelajari perubahan warna kulit buah (degreening) yang dikaitkan dengan kesegaran, daya simpan (shelf life), dan karakter kematangan pascapanen buah naga merah dalam rangka menentukan umur panen optimum.

\section{BAHAN DAN METODE}

Buah naga merah untuk percobaan (buah uji) diperoleh dari kebun Sabisa Farm, Sindang Barang, Bogor yang terletak di 6 $6^{\circ} 35^{\prime} 16^{\prime \prime} \mathrm{LS}, 106^{\circ} 46^{\prime}$ BT dengan elevasi 219 $\mathrm{m}$ di atas permukaan laut. Buah naga dipersiapkan dengan penandaan bunga pada bulan Desember 2017 sampai Januari 2018. Analisis pascapanen dilaksanakan pada bulan Januari sampai Maret 2018 di Laboratorium Pascapanen, Departemen Agronomi dan Hortikultura, Fakultas Pertanian, Institut Pertanian Bogor.

Buah naga untuk uji dipersiapkan dengan rancangan kelompok lengkap teracak dengan perlakuan 5 taraf umur panen yaitu $30,32,34,36$, dan 38 HSA. Persiapan buah uji dimulai dengan penandaan bunga antesis dengan interval 1 minggu sebanyak 5 kali penandaan bunga. Periode penandaan bunga diatur sebagai kelompok (ulangan), sehingga terdapat 25 satuan percobaan. Setiap satuan percobaan terdiri atas 6 buah, sehingga secara keseluruhan diperlukan 150 butir buah uji.

Penyiapan buah uji diawali dengan menandai bunga antesis dari 486 tiang buah naga. Bunga antesis dipilih dari pohon yang tumbuh optimal dan tidak ada serangan hama dan gejala penyakit tanaman. Penandaan bunga dilakukan 5 kali dengan interval 1 minggu, sebagai kelompok. Setiap periode penandaan ditandai 30 bunga yang telah antesis dengan 6 bunga untuk setiap umur panen. Pada saat panen 3 buah dari 6 buah uji dari setiap perlakuan digunakan untuk analisis kualitas buah yang dilakukan setelah warna kulit buah mencapai skala warna 6 (Gambar 1). Tiga buah sisanya diperam untuk uji daya simpan buah yang dihitung sejak buah mencapai skala warna 6 dengan tingkat kesegaran 5 sampai menurun ke tingkat kesegaran 1 (Gambar 2).

Selama masa pertumbuhan buah dilakukan pencatatan suhu maksimum dan minimum harian menggunakan 


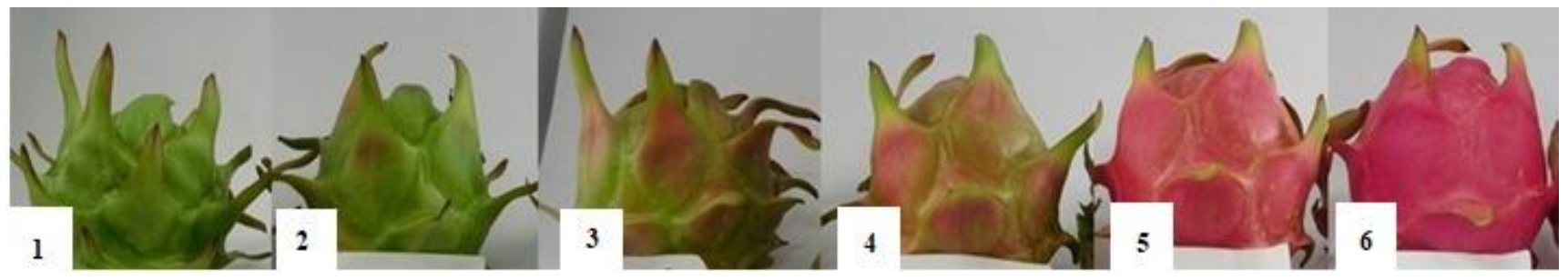

Gambar 1. Skala warna kulit buah naga merah; 1) 100\% hijau, 2) 1-25\% merah, 3) 26-50\% merah, 4) 51-75\% merah, 5) 76-99\% merah, dan 6) 100\% merah; Skala warna 1 sampai 5 mengacu pada Hua et al. (2018), skala warna 6 berdasarkan fakta lapangan warna buah dipanen di Sabisa Farm

termometer maksimum-minimum. Suhu rata-rata harian digunakan untuk menghitung akumulasi satuan panas $\left({ }^{\circ} \mathrm{C}\right.$ hari) dari antesis hingga buah dipanen. Suhu dasar yang digunakan untuk menghitung satuan panas mengacu pada hasil penelitian Nerd dan Mizrahi (1998) pada buah naga berkulit kuning yaitu $7{ }^{\circ} \mathrm{C}$.

Buah uji dipanen sesuai dengan kelompok dan umur panen yaitu 30, 32, 34, 36, dan 38 HSA. Buah panenan selanjutnya diangkut ke laboratorium untuk pengamatan dan pengukuran pascapanen. Pengamatan pascapanen dilakukan saat kulit buah mencapai skala warna 6 dan pada akhir masa pemeraman (tingkat kesaegaran 1).

Warna kulit buah diamati sejak panen hingga mencapai skala warna 6. Setelah kulit buah mencapai nilai skala warna 6 , dipilih 3 buah secara acak untuk dianalisis kualitas fisik dan kimianya.Tiga buah sisanya disimpan untuk diamati perubahann kesegarannya hingga mencapai tingkat kesegaran 1 (lewat matang). Pada tahap lewat matang juga dilakukan pengamatan kualitas fisik dan kimia buah. Buah panen yang sudah mencapai warna kulit skala 6 langsung dianalisis dan diperam sampai mencapai skor kesegaran 1 .

Pengamatan kriteria pascapanen mengacu pada penelitian yang dilakukan oleh Istianingsih dan Efendi (2013). Peubah yang diamati meliputi warna kulit buah, persentase susut bobot, kesegaran buah, umur simpan, kelunakan buah, kandungan padatan terlarut total (PTT), kandungan asam tertitrasi total (ATT) dan kandungan vitamin $\mathrm{C}$ daging buah.
Warna kulit buah diamati dengan skoring warna yang menghasilkan 6 skala warna kulit mengacu pada penelitian Hua et al. (2018). Kesegaran buah diamati secara kualitatif dengan munsell color chart yang menunjukkan 3 komponen warna yaitu hue, value dan chroma. Pengamatan kesegaran buah dilakukan terhadap warna kulit, warna sisik dan ketahanan buah terhadap busuk buah.pada tingkat kesegaran 5, mengacu pada penelitian Istianingsih dan Efendi (2013).

Bobot buah panen ditimbang sebagai bobot awal buah. Susut bobot dihitung sebagai persentase selisih bobot buah awal pada saat panen dengan bobot buah pada tingkat kesegaran 1. Umur simpan dihitung selama penyimpanan sejak buah mencapai skala warna 6 dengan tingkat kesegaran 5 hingga tingkat kesegaran 1. Pada saat buah mencapai skala warna 6 , dilakukan pengukuran kelunakan kulit buah dan kelunakan daging buah. Kelunakan buah diukur kembali pada saat kesegaran buah menurun sampai tingkat kesegaran 1.

Pada awal dan akhir penyimpanan dilakukan pengukuran kualitas kimia buah yang meliputi kandungan PTT, kandungan ATT sebagai asam malat, dan kandungan vitamin C. Kandungan PTT diukur dengan handrefractometer mengacu pada Bradley (2010). Kandungan ATT ditentukan dengan titrasi penetralan asam malat dengan titrant larutan $\mathrm{NaOH} 0.01 \mathrm{~N}$, mengacu pada Sadler dan Murphy (2010). Kandungan vitamin C ditentukan dengan titrasi iodometric yang mengacu pada metode pengukuran vitamin C dari University of Canterbury (2018).
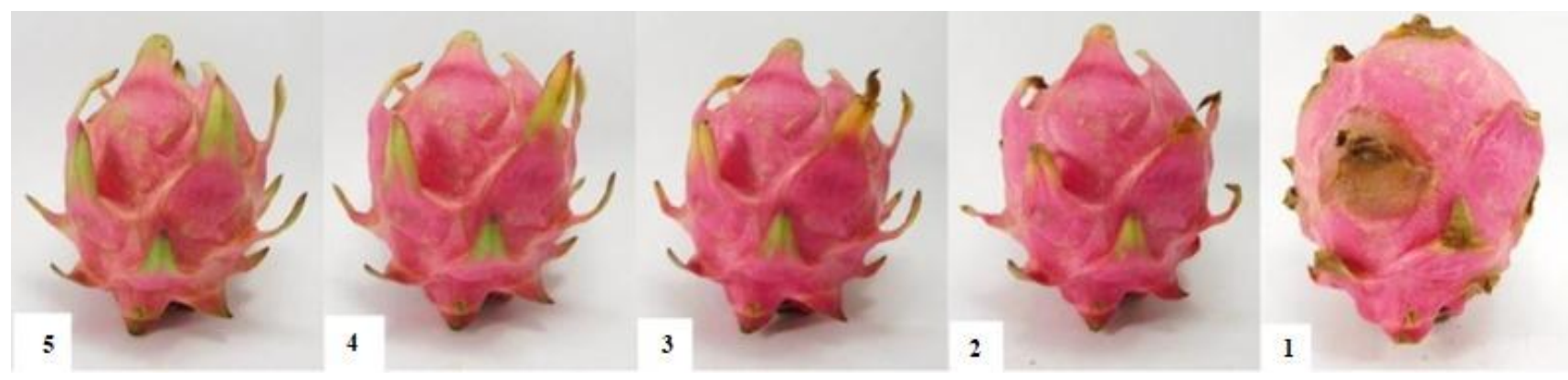

Gambar 2. Skor kesegaran buah naga merah dari awal sampai akhir pemeraman; 5 (sangat segar): sisik segar dan kehijauan, 4 (segar): sisik $\leq 30 \%$ sisik menguning, 3 (cukup segar): 30-100\% sisik berwarna kuning dan layu, 2 (kurang segar): 100\% sisik kering, kulit buah layu dan mengeriput, 1 (lewat matang): buah lunak dan mulai membusuk (mengacu pada Istianingsih dan Efendi, 2013) 
Data yang diperoleh dianalisis dengan uji $\mathrm{F}$ pada aplikasi SAS (Statistical Analysis System) versi 9.1. Jika hasil uji F menunjukkan pengaruh umur panen nyata, maka dilanjutkan uji beda nilai tengah menggunakan Duncan Multiple Range Test (DMRT) pada taraf 5\%.

\section{HASIL DAN PEMBAHASAN}

\section{Umur Panen dan Daya Simpan Buah}

Umur panen 30 sampai 38 HSA jika dikonversi ke akumulasi satuan panas maka terjadi peningkatan $39^{\circ} \mathrm{C}$ hari setiap dua hari. Peningatan terbesar terjadi antara umur 36 ke 38 HSA sebesar $49^{\circ} \mathrm{C}$ hari dan terkecil pada umur 34 ke 36 HSA sebesar $28{ }^{\circ} \mathrm{C}$ hari (Gambar 3A). Perbedaan umur panen dari 30 sampai 38 HSA tidak mempengaruhi bobot buah dipanen, kecuali bobot buah 30 HSA yang nyata lebih kecil dibandingkan dengan umur panen lainnya (Gambar 3B). Hal ini menunjukkan bahwa buah naga merah pada umur 32-38 HSA telah mencapai ukuran buah maksimal, seperti hasil penelitian Hua et al. (2018) yang mendapatkan tahap matang penuh buah naga merah adalah 28-30 HSA.

Umur simpan buah sejak buah mencapai skala warna kulit 6 (tingkat kesegaran 5) hingga tingkat kesegaran 1 sesuai dengan lamanya buah mencapai skala warna kulit 6. Umur simpan terpendek didapat pada buah 30 HSA dan terlama pada buah 34 dan 36 HSA (Gambar 3C). Hal ini sesuai dengan hasil yang didapat oleh Istiningsih dan Efendi (2015) yang menunjukan bahwa pada buah naga Super Red yang dipanen pada 35 HSA dapat disimpan dalam suhu
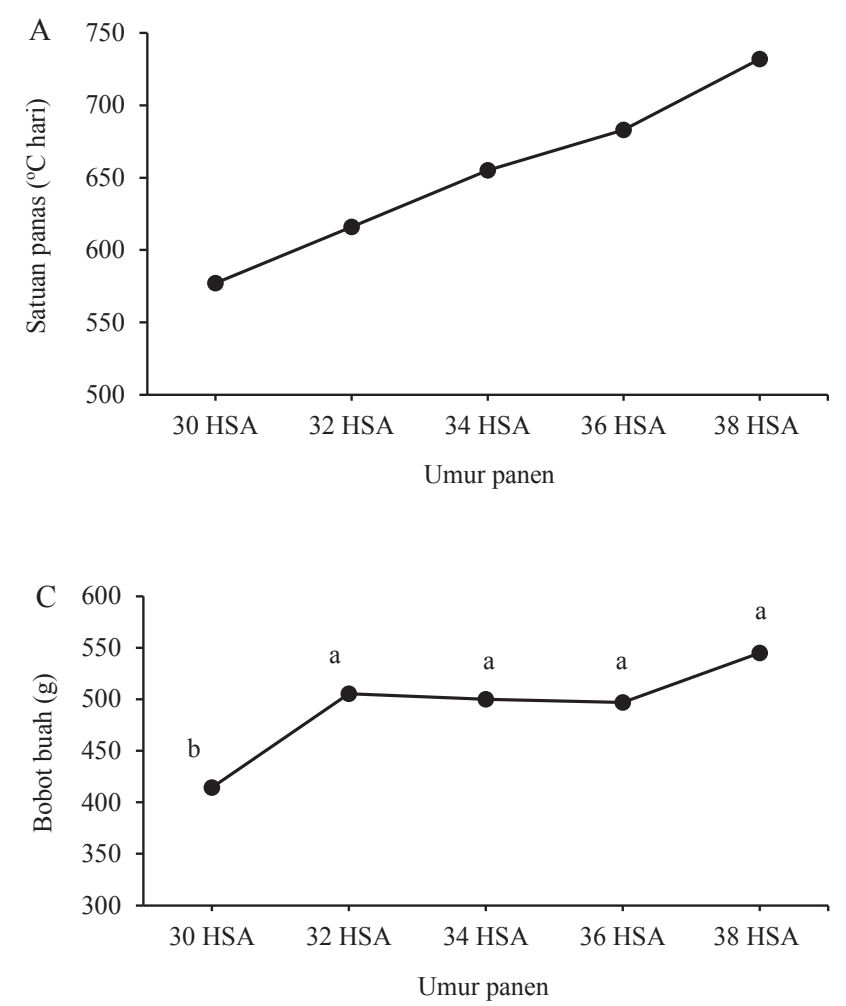

Gambar 3. Satuan panas (A), umur simpan (B), bobot buah (C), dan susut bobot (D) buah naga merah dari 5 umur panen; HSA: hari setelah antesis, huruf di atas titik pada kurva menunjukkan hasil uji beda nilai tengah dengan DMRT 5\%

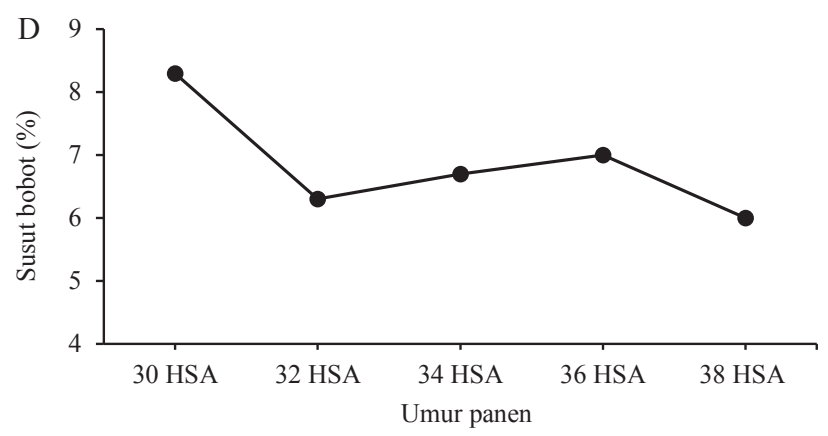

ruang hingga 7 hari setelah panen (HSP) dan dapat disimpan sampai $28 \mathrm{HSP}$ pada suhu penyimpanan $15^{\circ} \mathrm{C}$. Umur panen tidak mempengaruhi susut bobot buah setelah disimpan dari kesegaran 5 menjadi kesegaran 1 (Gambar 3D).

Umur panen mempengaruhi penurunan kesegaran buah jika dihitung sejak pemanenan. Buah 30 HSA memerlukan waktu 6 hari dari skala warna kulit 2 menjadi berwarna merah 100\% (skala warna kulit 6), dan buah 32 HSA memerlukan waktu 3 hari dari skala warna kulit 4 menjadi skala warna kulit 6 . Buah 30 HSA dan 34 HSA mengalami penurunan kesegaran dari skala 5 ke skala 1 masing-masing memerlukan waktu selama 4 dan 7 hari penyimpanan. Buah yang dipanen pada 34, 36, dan 38 HSA dari tingkat kesegaran 5 menjadi tingkat kesegaran 1, berturut-turut memerlukan waktu 12, 12, dan 11 HSP.

Pengamatan perubahan warna pada percobaan ini hanya memperhatikan perubahan warna kulit dan kesegaran buah. Perubahan warna daging buah belum diamati. Oleh karena itu diperlukan penelitian terhadap warna daging buah dari saat panen hingga tingkat kesegaran 1, mengingat dewasa ini buah naga selain dinilai kualitasnya untuk dikonsumsi segar, juga dinilai kandungan pigmen betasianinnya seperti pada percobaan-percobaan yang telah dilakukan oleh Naderi et al. (2012), Lorith dan Kanlayavattanakul (2013) dan Hua et al. (2018).

\section{Parubahan Warna Kulit Pascapanen}

Kulit buah yang dipanen pada 30 HSA memiliki skala warna kulit 2 dan memerlukan waktu 6 HSP untuk mencapai

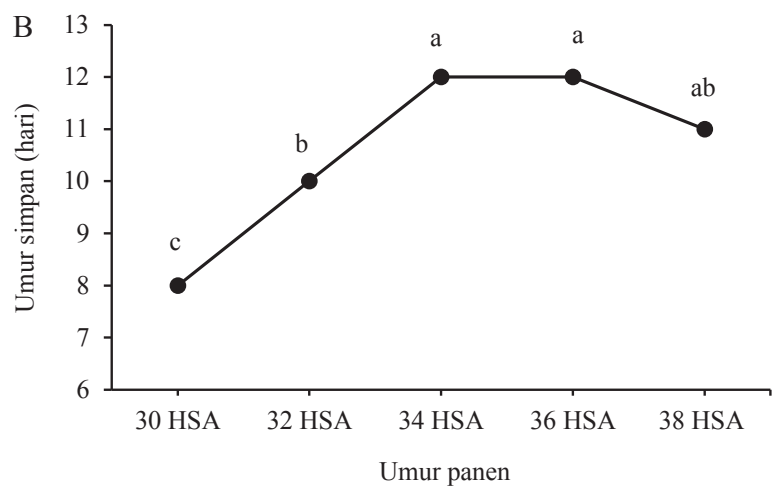


skala warna 6 . Buah yang dipanen pada 32 HSA memiliki skala warna kulit 4 dan memerlukan waktu 3 hari untuk mencapai skala warna 6 , sedangkan buah yang dipanen pada 34, 36, dan 38 HSA telah mencapai skala warna kulit 6 pada saat dipanen (Gambar 4).

Perubahan warna kulit buah setelah panen di atas menunjukkan bahwa buah naga merah mengalami perubahan warna kulit pascapanen yang serupa dengan perubahan warna kulit pascapanen pada buah alpukat kultivar Hass yang juga mengalami perubahan warna kulit buah akibat penurunan kandungan klorofil dan peningkatan kandungan antosianin pada 4-5 HSP (Cox et al., 2004). Proses perubahan warna kulit pascapanen buah non-klimakterik juga terjadi pada buah jeruk (Paul et al., 2012)., tetapi tidak terjadi pada anggur berwarna (He et al., 2010), sehingga warna kulit buah anggur merupakan kriteria panen penting (Kayesh et al., 2013). Analogi dengan perubahan warna buah alpukat Hass dengan pigmen dominan warna kulitnya antosianin, proses degreening pada kulit buah jeruk, dan proses pewarnaan kulit buah anggur berwarna, maka dapat disimpulkan bahwa kulit buah naga merah yang dipanen sebelum mencapai kematangan penuh juga mengalami proses degreening yang terjadi akibat dari penurunan kandungan klorofil dan peningkatan pigmen betasianin. Hal ini sesuai hasil peneitian Rooban et al. (2016) pada mangga (klimakterik) dan jambu mete (non-klimakterik) yeng mendapatkan bahwa kandungan antosianin atau karoten pada buah muda rendah dan meningkat pada tahap buah lewat matang, baik pada buah klimakterik maupun buah non-klimakterik.

Perubahan warna kulit yang terkait dengan kesegaran buah juga terjadi pada buah naga merah selama penyimpanan. Hasil analisis kesegaran buah yang ditunjukkan dengan perbandingan warna sisik buah pada tingkat kesegaran 5 dan tingkat kesegaran 1 menunjukkan terjadinya penurunan warna hijau dan peningkatan warna kuning. Warna dominan sisik pada tingkat kesegaran 5 hijau-kuning ( $5 \mathrm{GY}$ ) dengan kualitas warna yang hampir sama pada kisaran 5/6 hingga $6 / 8$. Setelah buah menurun kesegarannya menjadi tingkat kesegaran 1, maka warna dominan sisik menjadi kuning (10 Y) dengan kualitas warna yang hampir ssama pada 8/6 hingga 8.55/8, kecuali buah 32 HSA dan 38 HSA, karena sisik mengering (Gambar 5). Hal ini menunjukkan bahwa pada buah naga yang disimpan pada skala warna 6 , mengalami peningkatan warna kuning dan penurunan warna hijau pada sisik, yang sesuai dengan hasil penelitian Le Bellec et al. (2006).

\section{Umur Panen dan Kelunakan Buah}

Kelunakan kulit dan daging buah naga merah pada skala warna kulit 6 berbanding lurus dengan umur panen. Buah 30 HSA memiliki kelunakan kulit dan daging buah terendah, kemudian disusul oleh buah 32 HSA dan buah 34 HSA. Kulit buah 36 dan 38 HSA memiliki kelunakan yang sama dan nyata lebih lunak dibandingkan dengan kulit buah 32 dan 34 HSA. Kelunakan daging buah pada skala warna kulit 6, memiliki pola serupa dengan kelunakan kulit buah. Pada tingkat kesegaran 1, kelunakan kulit buah 30 hingga 38 HSA relatif sama. Buah 38 HSA memiliki kelunakan buah tertinggi dan berbeda nyata dibanding kekerasan buah 30-36 HSA. Kelunakan daging buah pada tingkat kesegaran 1 terlihat menunjukkan gradasi sesuai dengan umur panen. Buah 30 dan 32 HSA memiliki kelunakan daging buah yang sama, demikian juga kelunakan daging buah 34 dan 36 HSA. Buah 30 HSA memiliki daging yang lebih keras

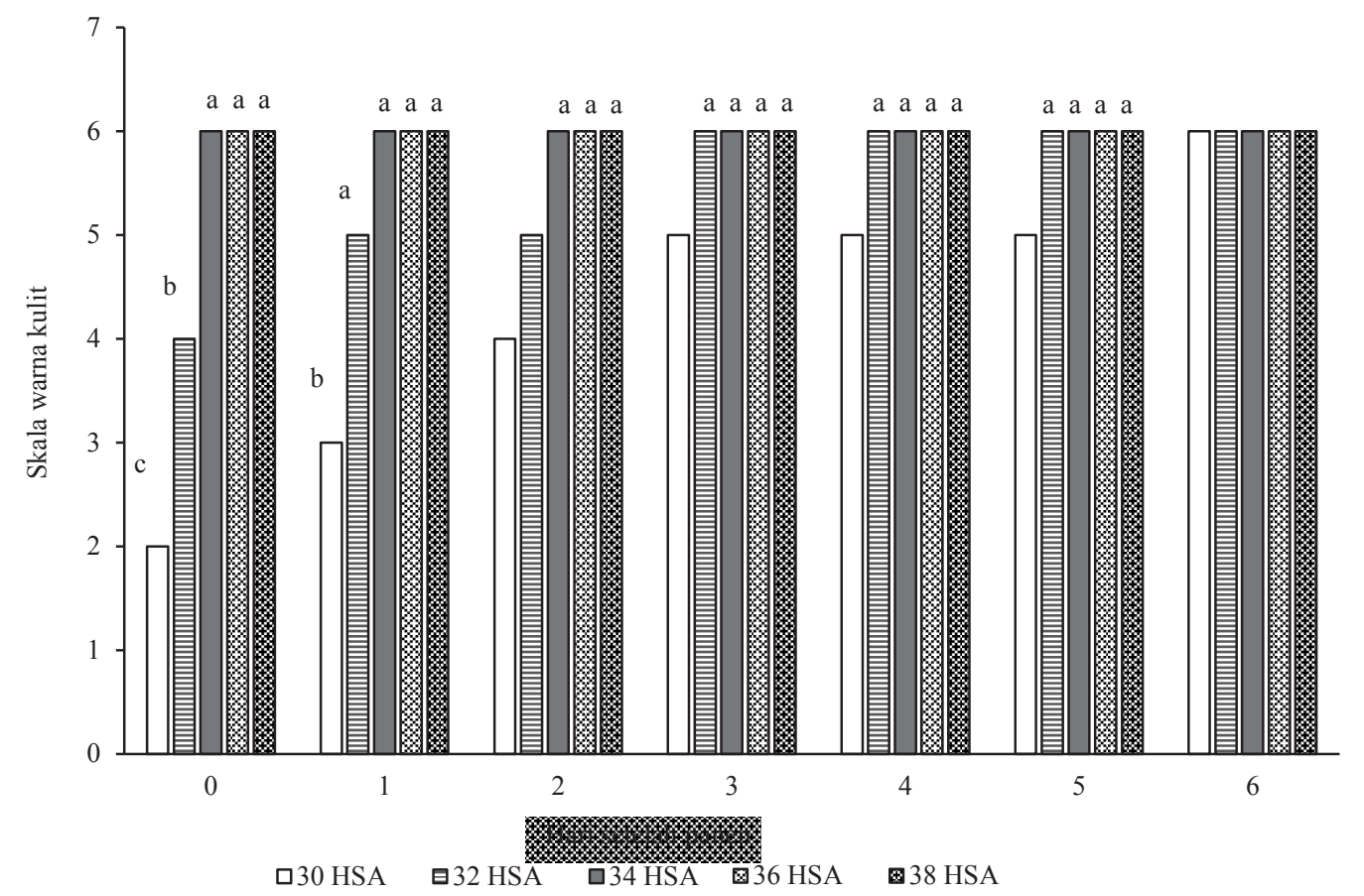

Gambar 4. Perubahan warna kulit buah naga dari 5 umur panen; HSA = hari setelah antesis, huruf di atas batang menunjukkan hasil uji beda nilai tengah dengan DMRT 5\% 

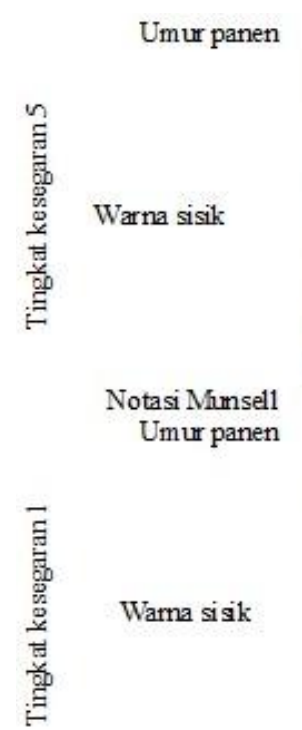

Notasi Munsel1

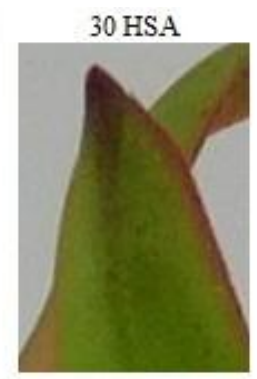

5 GY $5 / 6$ 30 HSA

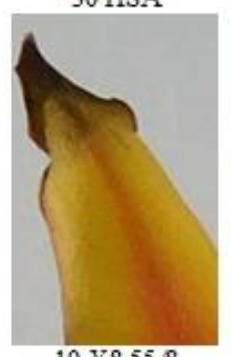

$10 \mathrm{Y} 8.55 / 8$
32 HSA

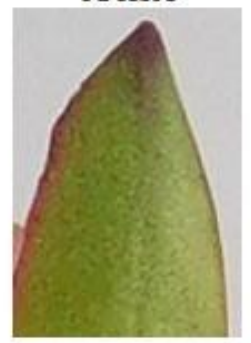

5 GY $6 / 6$

$32 \mathrm{HSA}$

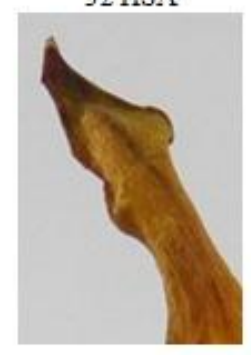

34 HSA

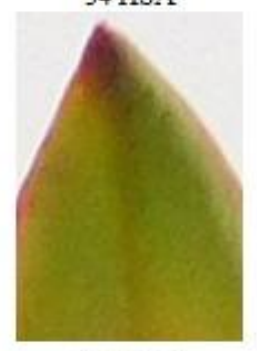

5 GY $6 / 8$

34 HSA

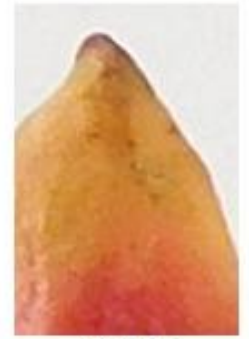

10 Y $8 / 6$
$36 \mathrm{HSA}$

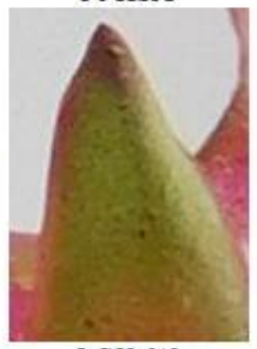

5 GY $6 / 6$

$36 \mathrm{HSA}$

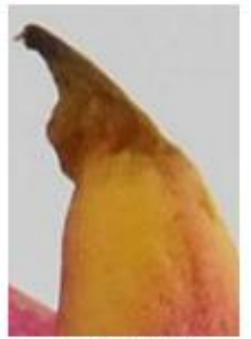

10 Y $8.5 / 8$
$38 \mathrm{HSA}$

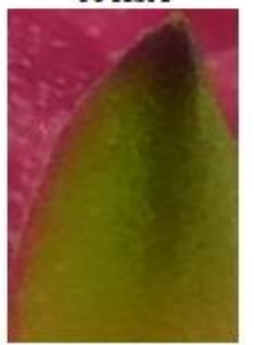

5 GY $5 / 6$

$38 \mathrm{HSA}$

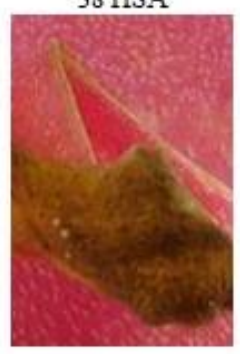

Gambar 5. Warna sisik buah naga pada kesegaran 5 dan kesegaran 1 menurut umur panen; HSA = hari setelah panen, warna sisik kesegaran 5: 5 GY: hijau kekuningan, warna sisik pada kesegaran 110 Y: kuning

dibanding buah yang dipanen pada umur yang lebih tua. Pola kelunakan daging buah pada tingkat kesegaran 1 masih menyerupai kelunakan daging pada kesegaran 5 (Gambar 6). Hal ini menunjukkan bahwa selama penyimpanan buah naga merah masih mengalami proses fisiologi, sehingga terjadi perbedaan kelunakan. Proses fisiologi pada buah yang dipanen tua lebih intensif dibandingkan dengan buah yang dipanen muda. Hal ini sesuai dengan hasil percobaanpercobaan sebelumnya diantaranya oleh Istiningsih dan Efendi (013) dan Coudhury et al. (2018),

\section{Umur Panen dan Kualitas Kimia Buah}

Selama proses pematangan buah di pohon, kandungan PTT meningkat sesuai dengan umur panen, yang terlihat pada kandungan PTT pada buah yang telah mencapai skala warna kulit 6. Kandungan PTT terendah diperoleh pada buah 30 HSA yang nyata lebih rendah dibandingkan dengan kandungan PTT buah yang dipanen lebih tua. Kandungan PTT tersebut tetap bertahan pada buah yang kesegarannya telah turun menjadi tingkat kesegaran 1 (Gambar 7A). Kandungan ATT pada tingkat kesegaran 5 berbanding terbalik dengan umur panen. Semakin tua umur panen, kandungan ATT pada tingkat kesegaran 5 semakin rendah. Kandungan ATT terendah didapat pada buah yang dipanen pada 36 dan 38 HSA. Pada buah dengan tingkat kesegaran 1, kandungan ATT terlihat stabil dan hampir sama dengan kandungan ATT buah pada tingkat kesegaran 5 yang dipanen pada 36 atau 38 HSA (Gambar 7B). Perubahan kandungan PTT dan ATT pada buah dengan tingkat kesegaran 5 mengakibatkan nilai PTT/ATT yang mirip polanya dengan kandungan PTT pada kesegaran 5. Nilai PTT/ATT buah pada tingkat kesegaran
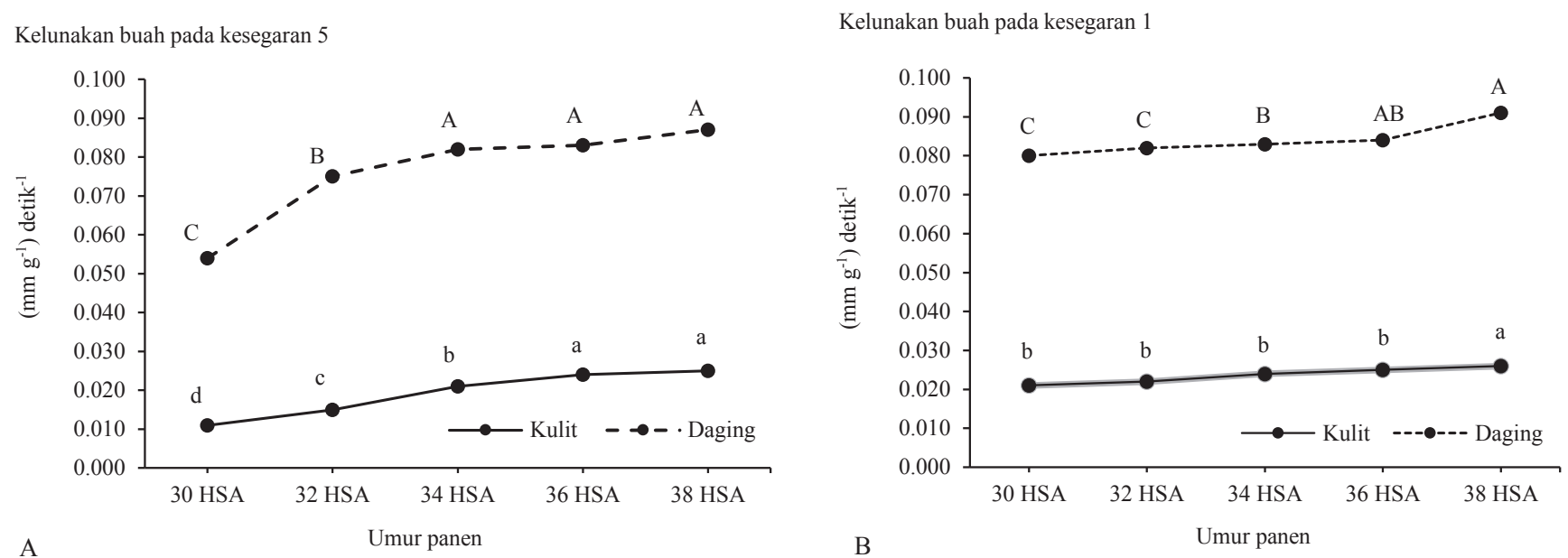

Gambar 6. Kelunakan kulit dan daging buah naga; (A) kelunakan pada skala warna kulit 6 (tingkat kesegaran 5), (B) kelunakan pada tingkat kesegaran 1, HSA: hari setelah antesis 

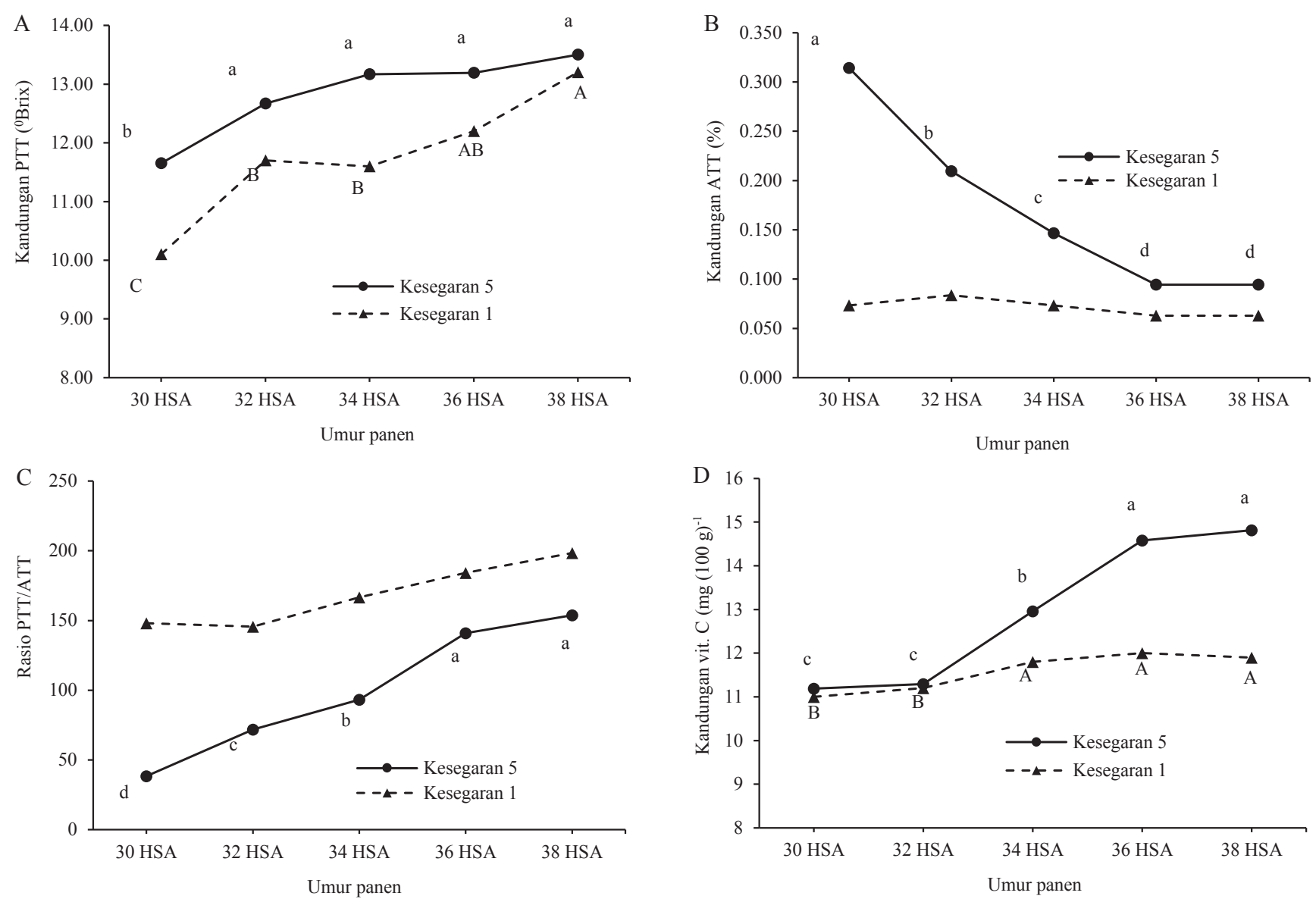

Gambar 7. Kualitas kimia buah naga pada tingkat kesegaran 5 dan 1 dari 5 umur panen; (A) PTT, (B) kandungan ATT, (C) rasio PTT/ATT, dan (D) kandungan vitamin C (D), HSA = hari setelah antesis

1 terlihat stabil sesuai dengan kandungan PTT-nya tetapi tidak berbeda nyata antar umur panen buah (Gambar 7C). Dengan memperhatikan kandungan PTT-nya, maka buah yang dipanen 30 sampai 38 HSA layak untuk dipasarkan jika mengacu standar mutu buah naga putih dari Direktorat Budidaya Tanaman Buah (2009) sebesar $11{ }^{\circ}$ Brix. Hasil percobaan ini sesuai dengan hasil yang diperoleh pada penelitian De Freitas dan Mitcham (2013) yang menyatakan bahwa tingkat kelayakan konsumsi tertinggi buah naga merah didapat pada buah yang dipanen pada tingkat matang penuh di pohon. Tingkat matang penuh pada penelitian ini telah dicapai pada umur 34 HSA yang jika dikonversi dengan akumulasi satuan panas tercapai pada akumulasi satuan panas $655^{\circ} \mathrm{C}$ hari.

Buah yang dipanen pada 34 HSA juga memiliki mutu konsumsi yang baik ditinjau dari kandungan vitamin $\mathrm{C}$. Kandungan vitamin $\mathrm{C}$ pada buah dengan tingkat kesegaran 1 dari buah yang dipanen pada 34 HSA nyata lebih tinggi dibandingkan kandungan vitamin $\mathrm{C}$ dari buah yang dipanen pada 30-32 HSA. Kandungan vitamin C pada buah dengan tingkat kesegaran 1, dari buah yang dipanen paa 30-32 HSA sama dengan kandungan vitamin $\mathrm{C}$ buah pada tingat kesegaran 5, sedangkan kandungan vitamin $\mathrm{C}$ buah dengan kesegaran 1 dari buah 34-38 HSA turun $15 \%$ pada buah 34 HSA hingga $27 \%$ pada buah 36 dan 38 HSA.

\section{KESIMPULAN}

Buah naga merah mencapai matang penuh di pohon, dengan warna kulit mencapai skala 6 (100\% merah) pada 34 HSA dengan akumulasi satuan panas $655^{\circ} \mathrm{C}$ hari. Buah naga merah yang dipanen pada 30 dan 32 HSA mengalami degreening hingga mencapai warna merah 100\% masingmasing selama 6 dan 3 hari setelah panen. Buah umur 34 HSA nyata lebih lunak dibanding buah yang dipanen pada 30 dan 32 HSA tetapi lebih keras dibanding buah 36 dan 38 HSA. Umur simpan buah 30 dan 32 HSA lebih pendek dibandingkan dengan buah 34, 36, dan 38 HSA. Umur panen tidak mempengaruhi bobot buah, kecuali buah 30 HSA memiliki bobot buah terkecil. Umur panen tidak mempengaruhi persen susut bobot. Buah 30 HSA memiliki daya simpan terpendek. Buah 32 HSA memiliki daya simpan yang lebih pendek dibandingkan dengan buah 34 dan 36 HSA, tetapi tidak berbeda dengan buah yang dipanen pada 38 HSA. Umur panen relatif tidak mempengaruhi kandungan PTT buah baik pada saat mencapai matang penuh maupun setelah kesegarannya menurun hingga tingkat kesegaran 1. Kandungan PTT buah pada percobaan ini masih memenuhi standard minimal layak pasar jika menggunakan standard minimal buah naga merah berdaging putih sebesar 11 ${ }^{\circ}$ Brix, 


\section{DAFTAR PUSTAKA}

Bradley, R.L. 2010. Moisture and total solid analysis. In S.S. Nielsen (Eds.). Food Analysis Fourth Edition. Springer. New York, US.

Choudhury, A.G., J. Sen, M. Barman, S. Das. 2018. Technological advancement for sustainable postharvest quality and storage of dragon fruit [Hylocereus species (Haworth) Britton \& Rose]. Global Hi-Tech. Hort. 6:117-132.

Cox, K.A., T.K. McGhie, A. White, A.B. Woolf. 2004. Skin colour and pigment changes during ripening of 'Hass' avocado fruit. Postharvest Biol. Tec. 31:287-294.

De Freitas, S.T., E.J. Mitcham. 2013. Quality of pitaya fruit (Hylocereus undatus) as influenced by storage temperature and packing. Sci. Agric. 70:257-262.

Direktorat Budi Daya Tanaman Buah. 2009. Pedoman Baku Budi Daya (Standard Operating Procedure/SOP) Buah Naga (Hylocereus undatus) Kabupaten Sleman. Departemen Pertanian, Jakarta, ID.

Hidayah, E., G.A. Fatma, L. Badriyah, Y.C. Hariadi. 2016. Optimalisasi Lama Pencahayaan dengan Menggunakan Lampu Bohlam pada Budidaya Buah Naga dalam Kondisi Off Season. Seminar Nasional Jurusan Fisika FMIPA UM 2016, Malang, Jawa Timur. Indonesia. 6 Agustus 2016.

He, F., L. Mu, G.L. Yan, N.N. Liang, Q.H. Pan, J. Wang, M.J. Reeves, C.Q. Duan. 2010. Biosynthesis of anthocyanin and their regulation in colored grapes. Molecules 15:9057-9091. Doi:10.3390/ molecules5129057.

Hoa, T.T., C.J. Clark, B.C. Waddell, A.B. Woolf. 2006. Postharvest quality of dragon fruit (Hylocereus undatus) following disinfesting hot air treatments. Postharvest Biol. Technol. 41:62-69.

Hua, Q., C. Chen, N.T. Zur, H. Wang, J. Wu, J. Chen, Z. Zhang, G. Zhao, G. Hu, Y. Qin. 2018. Metabolomic of pitaya fruit from three red-skinned cultivars with different pulp color. Plant Physiol. Biochem. 126:11125.

Hua, Q., Q. Zhou, S. Gan, J. Wu, C. Chen, J. Li, Y. Ye, J. Zhao, G. Hu, Y. in. 2016. Proteomic analysis of Hylocereus polyrhizus reveals metabolic pathway changes. Int. J. Mol. Sci. 17:1606. Doi:10.3390/ ijms 17101606 .
Istianingsih, T., D. Efendi. 2013. Pengaruh umur panen dan suhu simpan terhadap umur simpan buah naga Super Red (Hylocereus costaricensis). J. Hort. Indonesia 4:54-61.

Jiang, C.R., Y.Y. Liao, T.S. Lin, C.L. Lee, C.R. Yen, W.J. Yang. 2012. The Photoperiod-regulated bud formation of red pitaya (Hylocereus sp.). HortScience 47:10631067.

Jiang, Y.L., Y.Y. Liao, M.T. Lin, W.J. Yang. 2016. Bud development in response to night-breaking treatment in the noninductive period in red pitaya (Hylocereus sp.). HortScience 51:690-696.

Kayesh, E., L. Shangguan, N.K. Korir, X. Sun, N. Bilkish, Y. Zhang, J. Han. 2013. Fruit skin color and the role of anthocyanin. Acta Physiol. Plant 35:2879-2800.

Khaimov, A., Y. Mizrahi. 2006. Effects of day-length, radiation, flower thinning and growth regulators on flowering of the vine cacti Hylocereus undatus and Selenicereus megalanthus. J. Hort. Sci. Biotechnol. 81:465-470.

Le Bellec, F., F. Vaillant, E. Imbert. 2006. Pitahaya (Hylocereus spp.): a new fruit crop, a market with a future. Fruits 61:237-250.

Lourith, N., Kanlayavattanakul M. 2013. Antioxidant and stability of dragon fruit peel colour. Agro FOOD industry Hi Tech. 24:56-58.

Maigoda, T.C., Darwis, A. Rizal, E. Yuliantini, Kamsiah, M. Mahyuddin, E. Wahyuni, Rachmawati, K. Heryati, Y. Lubis, P.S. Kurniawati, Mariati, Serilaila, E. Yorita, S. Sumiati, P. Efendi, Septiyanti, Sahidan, A. Widada, Yusmidiarti, S. Mulyati, H. Ali, Jubaidi. 2017. Red dragon fruit powder as a basic ingridient for functional foods rich in bioactive coumpounds, nutritional substances and antioxidants. Pak. J. Nutr. 16:714-718.

Mizrahi, Y. 2015. Thirty-one Years of Research and Development in the Vine Cacti Pitaya in Israel. Improving Pitaya Production and Marketing. https://www.fftc.org.tw/htmlarea_file/ activities/20150817121105/01-15P10.pdf Oktober 2020).

Naderi, N., H.M. Ghazali, A.S.M. Hussin, M. Amid, M.Y.A. Manap. 2012. Characterization and quantification of dragon fruit (Hylocereus polyrhizus) betacyanin pigments extracted by two procedures. Pertanika J. Trop. Agric. Sci. 35:33-40. 
Nerd, A., Y. Mizrahi. 1998. Fruit development and ripening in yellow pitaya. J. Amer. Soc. Hort. Sci. 123:560562.

Patil, P.D., S.P. Dehankar, P.D. Desai, Y.D. Bhujbal, V.P. Patil. 2019. Extraction and Characterisation of Betacyanin as a dye pigment from dragon fruit: A review. JETIR 6(1). https://www.researchgate.net/ publication/330513074.

Patwary, M.M.A., M.H. Rahman, H. Barua, S. Sarkar, M.S. Alam. 2013. Study on the growth and development of two dragon fruit (Hylocereus undatus) genotypes. The Agriculturists 11:52-57.

Paul, V., R. Pandey, G.C. Srivastava. 2012. The fading distinctions between classical patterns of ripening in climacteric and non-climacteric fruit and the ubiquity of ethylene-An overview. J. Food Sci. Technol. 9:121.

Priatni, S., A. Pradita. 2015. Stability study of betacyanin extract from red dragon fruit (Hylocereus polyrhyzus) peels. Procedia Chem. 16:438-444.

Rebecca, O.P.S., A.N. Boyce, S. Chandran. 2010. Pigment identification and antioxidant properties of red dragon fruit (Hylocereus polyrhizus). African J. Biotech. 9:1450-1454.

Rooban, R., M. Shanmugam, T. Venkatesan, C. Tamilmani. 2016. Pigment changes during different stages of fruit ripening of climacteric fruit of mango (Mangifera indica L.) and non-climacteric of fruit cashew apple (Anacardium occidentale L.). LSA 2:725-732.

Sadler, G.D., P.A. Murphy. 2010. pH and titratable acidity. In S.S. Nielsen (Eds.). Food Analysis Fourth Edition. Springer. New York, US.

Setyawati, H. 2019. Analisis kajian fisiologi tumbuhan budidaya buah naga (Hylocereus spp.) menggunakan lampu di Banyuwangi. Prosiding Symbion (Symposium on Biology Education), Prodi Pendidikan Biologi, FKIP, Universitas Ahmad Dahlan, 30 Agustus 2019. e-ISSN: 2528-5726.

Tran, D.H., C.R. Yen, Y.K.H. Chen. 2015. Flowering response of red pitaya germplasm collection to lighting addition. Intl. J. Biol. Life Agric. Sci. 9: http://scholarly.org/ display/flowering-responseof-a-red-pitaya-germplasm-collection-to-lightingaddition. 20 Oktober 2020.

University of Canterbury. 2018. Determination of Vitamin C Concentration by Titration. http://www.canterbury. ac.nz/media/documents/scienceoutreach/vitaminc_ iodine.pdf. 1 Februari 2018.

Woo, K.K., F.H. Ngou, L.S. Soong, P.Y. Tang. 2011. Stability of betalain pigment from red dragon fruit (Hylocereus polyrhizus). Amer. J. Food Tech. DOI: 10.3923/afjft.2011. 